\title{
Diagnosis, Treatment, and Prognosis of Syphilis in HIV Patient
}

\section{Mutia Devi ${ }^{*}$, Izazi Hari Purwoko ${ }^{1}$, Suroso Adi Nugrohoํ, Inda Astri Aryani ${ }^{1}$, Susanti Budiamal ${ }^{1}$,} Putri Laksmi Karim ${ }^{1}$

${ }^{1}$ Department of Dermatology and Venereology, Faculty of Medicine, Universitas Sriwijaya/ Dr. Mohammad Hoesin General Hospital, Palembang, Indonesia

\section{A R T I C L E I N F O \\ Keywords: \\ Syphilis \\ HIV \\ Diagnose \\ Treatment \\ Prognosis \\ *Corresponding author: \\ Mutia Devi \\ E-mail address: \\ drmutiadevi@gmail.com}

All authors have reviewed and approved the final version of the manuscript.

\section{https://doi.org/10.32539/bsm.v5i11.416}

\section{Introduction}

Syphilis is a sexually transmitted disease that is chronic or chronic, can attack all organs of the body, resembles various diseases (great imitator disease), has an asymptomatic latent period, and can recur.1,2 Human immunodeficiency virus (HIV) is a virus that attacks the immune system. HIV infection causes a decrease in the body's immunity so it is very easy to be infected with various other diseases. ${ }^{3}$ Syphilis also increase the risk of HIV transmission, because HIV can enter through genital ulcers (disorders of the skin barrier) in syphilis. ${ }^{1}$ Syphilis with HIV infection has an increase in HIV viral load and a decrease in CD4 T cell counts. ${ }^{1,4}$ Syphilis infection can increase the risk of HIV transmission by 3-5 times. ${ }^{5}$ The incidence of primary and secondary syphilis in the United States by the Centers for Disease Control (CDC) increased during 2000-2016, mainly due to the increase in MSM cases. In $2016,47.0 \%$ of cases of syphilis with HIV infection were MSM, $10.7 \%$ of men had sex with women, and $4.1 \%$ of women. ${ }^{6}$. Cases of primary and secondary syphilis with HIV positive status in 2017 were identified, $45.5 \%$ of cases were HIV-positive MSM, 8.8\% of cases where men having sex with women, and $4.5 \%$ cases were women. ${ }^{7}$ Penicillin is still the gold standard for the treatment of syphilis, with or without HIV coinfection. Serological tests for patients with HIV infection should be repeated at $1,2,3,6,9$, and 12 months. ${ }^{4}$ This literature review will discuss diagnosis, 
management, prevention, and prognosis of syphilis in HIV patients.

\section{Diagnosis}

The diagnosis of syphilis is based on a complete history, including sexual history, clinical manifestations, and examination. Direct examination to see the bacteria $T$. pallidum using a dark field microscope is the most sensitive and specific examination when there are durum ulcers and condylomata lata, but this examination is difficult because it is an invasive procedure. ${ }^{8}$ Specimens for syphilis examination were obtained from ulcerated lesions or erosions of the skin or mucosa, blood, and CSF. Polymerase chain reaction (PCR) and nucleic acid amplification test (NAAT) methods have now been developed to detect T. pallidum bacteria using fluid from skin lesions, blood, or CSF.8,9

HIV infection complicates the serological diagnosis of syphilis and the evaluation of the patient because there are differences in serological values for syphilis and HIV infection. ${ }^{10}$ All syphilis patients should be tested for HIV infection. In primary and secondary syphilis, if the results of the first HIV test are negative, they should be tested again for HIV 3 months later. ${ }^{11}$ The definitive diagnosis of syphilis is made if $\mathrm{T}$. pallidum is found on dark-field microscopy or PCR examination. A presumptive diagnosis of syphilis is made if the results of nontreponemal and treponemal examinations are reactive. The interpretation of the results of the syphilis examination can be seen in Figure 6.2

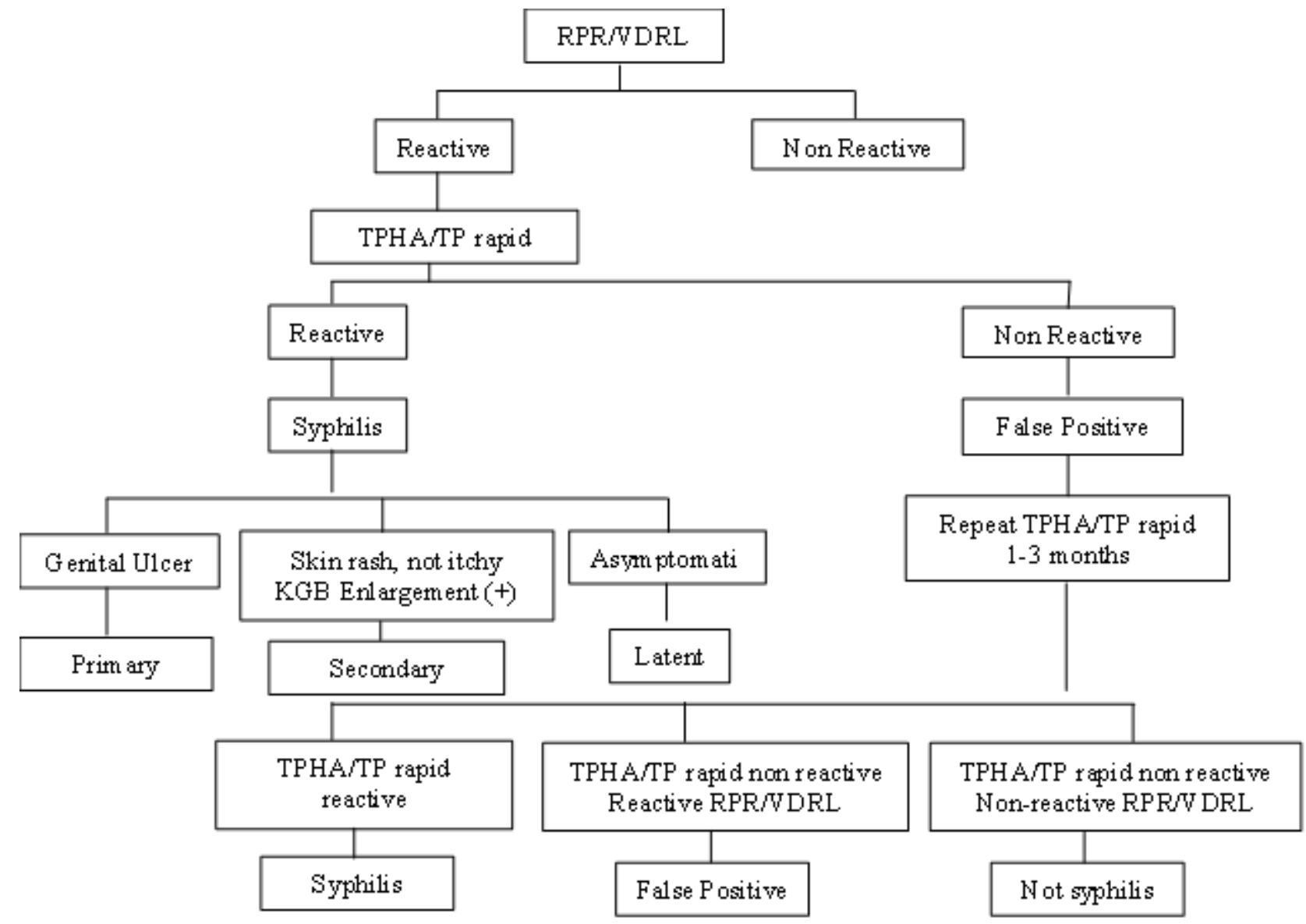

Figure 6. Algorithm interpretation of syphilis serology results. ${ }^{2}$ 
A serological examination is a tool for the diagnosis of syphilis in syphilis patients with HIV infection and without HIV infection. In the majority of syphilis patients with HIV infection can be diagnosed by serology examination, but there are differences in VDRL results in syphilis with HIV infection and without HIV infection. ${ }^{12}$ Standard examinations nontreponemal are VDRL and rapid plasma reagin (RPR) examinations. Nontreponemal antibody titers correlate with disease activity and are used to assess response to treatment. Reactive nontreponemal examinations must be confirmed by treponemal tests such as Treponema Pallidum Hemagglutination Assay (TPHA) or syphilis rapid examination (TP Rapid) to establish the diagnosis of syphilis. Nontreponemal antibodies that persist after therapy may indicate a failure of immune tolerance. ${ }^{12,9}$

False-negative serological results may occur in prozone phenomena and seronegative syphilis due to a serofast reaction ie, persistent reactive nontreponemal test results, even after treatment.1,2,10 The prozone phenomenon occurs because the nontreponemal antibody titer is very high, above the antigen level so that the antigen-antibody reaction does not occur. ${ }^{2}$ Serofast occurs in patients with appropriate management who achieve clinical recovery and no nontreponemal antibodies are found. ${ }^{11}$ Biological falsepositive results were found in $1 \%$ of cases and most of the titers were 1:8.1,2 False-positive results can be acute if they last less than six months and chronic if they last more than six months. ${ }^{13}$ False-positive nontreponemal test results can be associated with a variety of medical conditions and factors not associated with syphilis such as HIV infection, autoimmune conditions, immunization, pregnancy, injecting drug use, and old age.2,9 The interpretation of nontreponemal tests in syphilis patients with HIV infection and without HIV infection is generally not different. However, false-negative and false-positive results, prozone and serofast phenomena were found more frequently in patients with HIV infection than in patients without HIV infection. ${ }^{2}$

The cerebrospinal fluid examination was performed on syphilis patients with neurological disorders, visual impairment, hearing loss, cardiovascular symptoms, gumma, failure of serological therapy, advanced syphilis patients on tetracycline therapy, and HIV coinfected patients with advanced syphilis stage and CD4 count $350 / \mathrm{mm} 3$ and/ or serum VDRL/RPR > 1:32.2,11The white blood cell count, protein, RPR/VDRL and TPHA on CSF examination of syphilis patients with HIV infection and without HIV infection were different. The results of CSF examination support the diagnosis of neurosyphilis in patients with HIV infection and without HIV infection can be seen in table $4 .{ }^{2}$

Table 4. The criteria for the diagnosis of neurosyphilis are based on the examination of the cerebrospinal fluid. ${ }^{2}$

\begin{tabular}{lll}
\hline CSF Parameters & HIV $(-)$ & HIV $(+)$ \\
\hline White blood cell & $>5 \mathrm{ul}$ & $>20$ ul or $6-20 \mathrm{ul}$ \\
Protein & $>0.45 \mathrm{~g} / 1$ & $>0.45 \mathrm{~g} / 1$ \\
RPR/VDRL & + & + \\
TPHA & $>1: 320$ & $>1: 320$ \\
\hline
\end{tabular}

Syphilis with unreactive clinical and serological features of unclear interpretations may require skin biopsy, dark-field microscopy, or T. pallidum PCR to confirm the diagnosis. ${ }^{1,12}$ Skin biopsy of secondary syphilitic lesions has a variety of histopathological appearances related to the clinical picture. ${ }^{12,9}$ The basic feature of histopathological changes in syphilis is a perivascular infiltrate consisting of lymphocytes and plasma cells, which is a specific but not pathognomonic sign for syphilis. Histopathologic features include endarteritis obliterans and endophlebitis, endothelial proliferation, and thickening of blood vessel walls surrounded by infiltrates. 8,14 Histopathological features in syphilitic roseola are psoriasiform hyperplasia often accompanied by spongiosis, parakeratosis, dermal papillary, and perivascular or periadnexal edema, 
infiltrates dominated by lymphocytes and plasma cells,

and thickening of the vascular endothelium (Figure

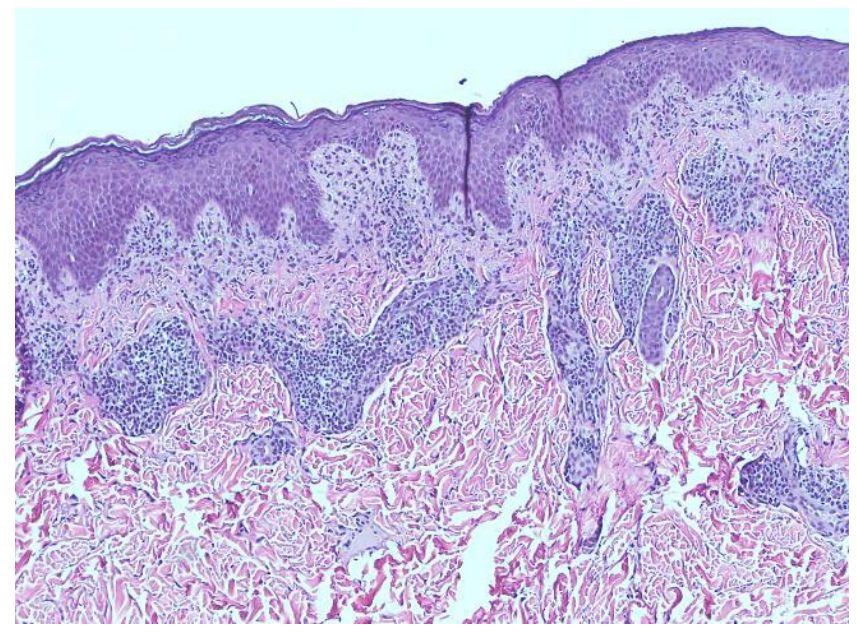

Figure 7. Histopathological appearance of an erythematous patch lesion in the posterior trunk region of a syphilitic patient with HIV infection, showing powdered inflammatory cells in the epidermis, dermis, and around the sebaceous glands (Fig.), impression benign skin lesions consistent with secondary syphilis (syphilitic roseola).

(Source: Photo collection of Departement of Dermatology and Venereology, Faculty of Medicine, Universitas Sriwijaya /Dr. Mohammad Hoesin, General Hospital, Palembang-Indonesia)

\section{Treatment}

Penicillin is still the gold standard for the treatment of syphilis, with or without HIV coinfection. Serological tests for patients with HIV infection should be repeated at $1,2,3,6,9$, and 12 months. ${ }^{4}$ Primary or secondary syphilis with HIV infection is treated the same as for syphilis without HIV infection. The drug of choice for all stages of secondary syphilis is benzathine penicillin G (BPG) 2.4 million units IM in a single dose.1,15,10 Primary or secondary syphilis infection with HIV infection without neurologic involvement at least three doses of benzathine penicillin 2.4 million units IM at one-week intervals. ${ }^{13}$ Procaine penicillin (PP) 1.2 million units can be an alternative therapy in the absence of BPG. ${ }^{15,16}$ Penicillin-allergic syphilis patients were given a regimen of doxycycline $100 \mathrm{mg}$ orally twice daily for 14 days and tetracycline $500 \mathrm{mg}$ four times a day for 14 days. All syphilis with HIV infection should undergo a neurologic examination. ${ }^{15,10,17}$ Primary or secondary syphilis with HIV infection should be evaluated for clinical and serological management failure at 3, 6, 9, 12, and 24 months after therapy. ${ }^{12,10}$ Patients with penicillin allergies should be desensitized. ${ }^{15,10}$ Syphilis treatment algorithm can be seen in Figure 8.18

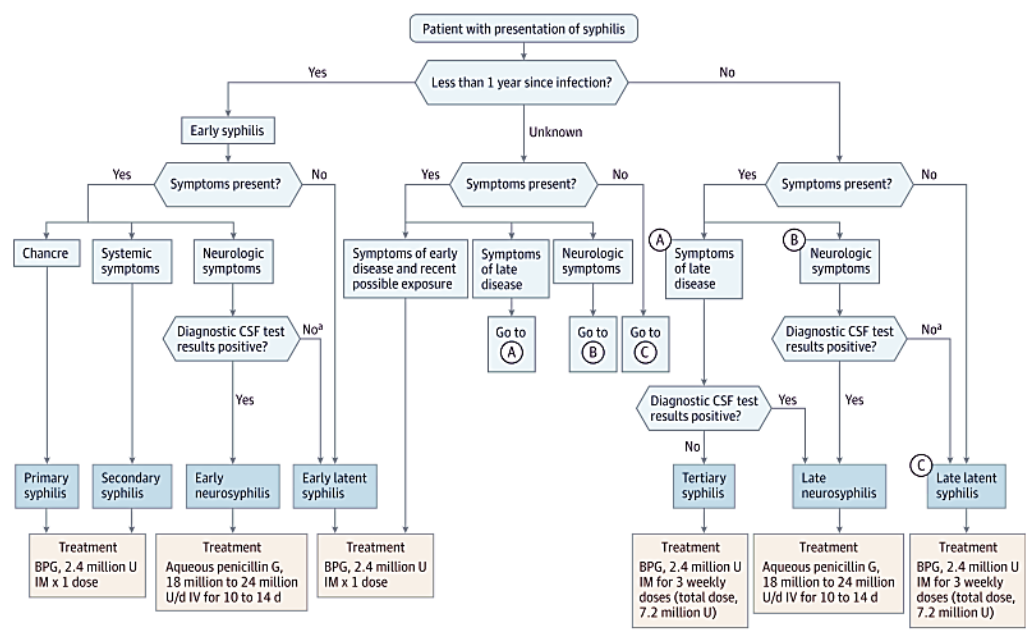

Figure 8. Syphilis treatment algorithm. ${ }^{18}$ 
The CDC's management recommendations for syphilis are independent of HIV infection status. ${ }^{10}$ Titers decreased more slowly in syphilis with HIV infection with appropriate treatment than in those without HIV infection, especially in patients with low initial diagnosis titers. Primary or secondary syphilis with HIV infection should be evaluated more frequently than syphilis without HIV infection.1,10 Management of primary and secondary syphilis can be seen in table 5. $16,15,10$

Table 5. Syphilis management in primary and secondary syphilis. ${ }^{16,15,10}$

\begin{tabular}{|c|c|c|c|}
\hline $\begin{array}{l}\text { Syphilis } \\
\text { Stadium }\end{array}$ & WHO (2016) ${ }^{15}$ & $\begin{array}{c}\text { Indonesian Ministry of } \\
\text { Health }(2016)^{16}\end{array}$ & $\mathrm{CDC}(2015)^{10}$ \\
\hline $\begin{array}{l}\text { Primary and } \\
\text { secondary } \\
\text { syphilis }\end{array}$ & $\begin{array}{l}\text { - } \text { BPG G 2.4 million } \\
\text { units IM, single dose or } \\
\text { PP } 1.2 \text { million units IM, } \\
10-14 \text { days } \\
\text { Alternative: } \\
\text { - } \quad \text { Doxycycline } 100 \mathrm{mg} \\
\text { PO for } 30 \text { days or } \\
\text { - Ceftriaxone 1g IM once } \\
\text { daily, for } 10-14 \text { days, } \\
\text { or } \\
\text { Azithromycin } 2 \\
\text { single dose PO } \\
\text { Pregnant mother: } \\
\text { BPG } 2.4 \text { million units } \\
\text { IM single dose or } \\
\text { PP } 1.2 \text { million IM units } \\
\text { once a day for } 10 \text { days } \\
\text { Alternative: } \\
\text { Erythromycin } 4 x 500 \\
\text { mg PO for } 14 \text { days or } \\
\text { Ceftriaxone } 1 \text { g IM } \\
\text { once daily for } 10-14 \\
\text { days or } \\
\text { Azithromycin } 2 \mathrm{~g} \text { PO } \\
\text { single dose }\end{array}$ & $\begin{array}{l}\text { BPG G } 2.4 \text { million units } \\
\text { IM, single dose } \\
\text { Alternative: } \\
\text { - PP } 1.2 \text { million units } \\
\text { IM, } 10-14 \text { days } \\
\text { - Doxycycline } 2 \times 100 \\
\text { mg PO for } 14 \text { days } \\
\text { Pregnant Women and } \\
\text { Penicillin Allergy: } \\
\text { - Decentitisation } \\
\text { - Erythromycin } 4 \times 500 \\
\text { mg PO for } 30 \text { days }\end{array}$ & $\begin{array}{l}\text { BPG } 2.4 \text { million units IM } \\
\text { single dose } \\
\text { Alternative: } \\
\text { - PP 600,000 IM units } \\
\text { per day for 10-14 } \\
\text { days } \\
\text { Ceftriaxone } 1 \mathrm{~g}-2 \mathrm{~g} \\
\text { SC/IV per day for } 10 \\
\text { days } \\
\text { Doxycycline } 2 \times 100 \\
\text { mg per day PO for } 14 \\
\text { days } \\
\text { Azithromycin } 2 \mathrm{~g} \text { PO } \\
\text { single dose } \\
\text { Pregnancy and Penicillin } \\
\text { Allergy: } \\
\text { Azithromycin } 2 \text { g PO } \\
\text { single dose } \\
\text { Infants and children: } \\
\text { BPG } 50,000 \text { units } / \mathrm{kg} \text { IM } \\
\text { single dose, maximum } \\
\text { 2.4 million units }\end{array}$ \\
\hline
\end{tabular}

The management of syphilis according to the 2017 Perdoski PPK is divided into education and drug administration. In education, sexual partners were told that they had to be treated, counseling about syphilis, modes of transmission, prevention, management, and the risk of being easily infected with HIV.19 The treatment of choice for the primary and secondary stages is benzyl benzathine penicillin G (BBPG), with a single dose of 2.4 million units of intramuscular injection, while in the latent stage 2.4 million units of BBPG are given an intramuscular injection every week on day 1.8 and 15 according to WHO guidelines. ${ }^{15,19}$ Patients were asked to wait for 30 minutes after the injection of BBPG. ${ }^{19}$ Alternative medicine if allergic to penicillin, the patient refuses injection or BBPG is not available is doxycycline $2 \times 100 \mathrm{mg}$ orally for 14 days for primary and secondary syphilis or 28 days for latent syphilis according to WHO guidelines. ${ }^{15,19}$ Doxycycline according to the Indonesian Ministry of Health can be given 2x100 mg orally for 30 days in primary and secondary syphilis and more than 30 days in latent syphilis. Pregnant women can be given erythromycin $4 \times 500 \mathrm{mg}$ orally for 30 days in primary and secondary syphilis, or more than 30 days in latent syphilis according to the Indonesian Ministry of Health. 16,19 Clinical and serological evaluation of therapy was performed at 1, 3, 6 and 12 months with criteria for recovery if VDRL or RPR titers decreased 4-fold within 6 months after treatment. ${ }^{19}$ 
Table 6. Syphilis management in advanced syphilis. ${ }^{16,15,10}$

\begin{tabular}{|c|c|c|c|}
\hline $\begin{array}{l}\text { Syphilis } \\
\text { Stadium }\end{array}$ & WHO (2016) 15 & $\begin{array}{c}\text { Indonesian Ministry of } \\
\text { Health (2016) }{ }^{16}\end{array}$ & $\mathrm{CDC}(2015)^{10}$ \\
\hline $\begin{array}{l}\text { Advanced } \\
\text { syphilis }\end{array}$ & 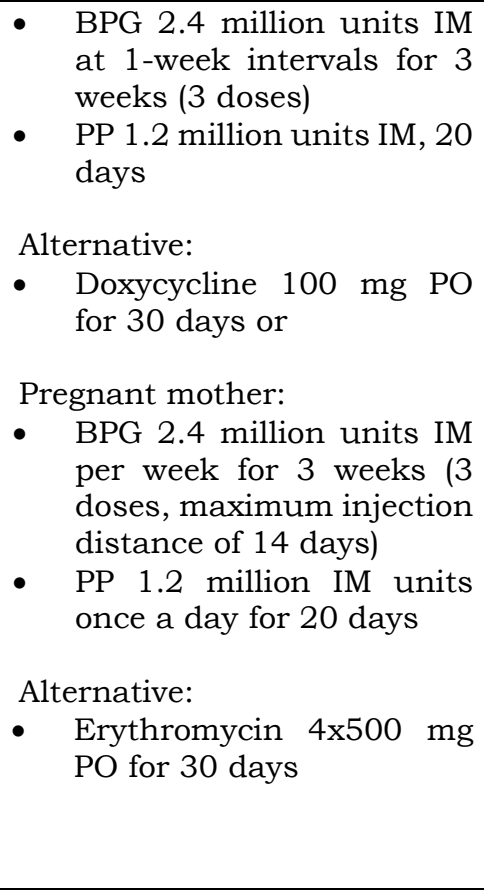 & $\begin{array}{l}\text { BPG } 2.4 \text { million units IM } \\
\text { at } 1 \text {-week intervals for } 3 \\
\text { weeks (3 doses) } \\
\text { Alternative: } \\
\text { - PP } 600,000 \text { million } \\
\text { units IM, } 10-14 \text { days } \\
\text { Doxycycline } 2 \times 100 \\
\text { mg PO for } 30 \text { days } \\
\text { Ceftriaxone } 1 \text { g IM } \\
\text { once daily for } 10-14 \\
\text { days } \\
\text { Pregnant Women and } \\
\text { Penicillin Allergy: } \\
\text { - desensitization } \\
\text { Erythromycin } 4 x 500 \\
\text { mg PO for } 30 \text { days }\end{array}$ & $\begin{array}{l}\text { BPG } 2.4 \text { million units IM } \\
\text { at } 1 \text {-week intervals for } 3 \\
\text { weeks ( } 3 \text { doses) } \\
\text { Penicillin allergy: } \\
\text { - PP } 600,000 \text { million } \\
\text { units once a day for } \\
10-14 \text { days } \\
\text { Doxycycline } 100 \mathrm{mg} \\
\quad 2 \times \text { for } 28 \text { days } \\
\text { Tetracycline } 500 \mathrm{mg} \\
\text { for } 28 \text { days } \\
\text { Pregnant mother: } \\
\text { BPG } 2.4 \text { million units IM } \\
\text { administered } 1 \\
\text { after an initial dose } \\
\text { Infants and children: } \\
\text { BPG } 50,000 \text { units } / \mathrm{kg} \mathrm{IM} \\
\text { in } 3 \text { doses at } 1-\mathrm{week} \\
\text { intervals (total } 150,000 \\
\text { units } / \mathrm{kg} \text {, maximum } \\
\text { dose } 7.2 \text { million units) }\end{array}$ \\
\hline
\end{tabular}

A fourfold increase in titer after treatment indicates reinfection or treatment failure. Re-infection should be assessed by clinical history and physical examination. Patients should be treated with benzathine penicillin G 7.2 million units (divided into 3 doses per week) if treatment fails. A CSF examination should be performed to determine if neurosyphilis is present and if any the patient should be treated for neurosyphilis. ${ }^{10}$ Management of neurosyphilis can be seen in table $7.16,15,10$

Table 7. Management of neurosyphilis. 16,15,10

\begin{tabular}{|c|c|c|c|}
\hline Syphilis Stadium & WHO $(2016)^{15}$ & $\begin{array}{c}\text { Indonesian Ministry of } \\
\text { Health }(2016)^{16}\end{array}$ & $\operatorname{CDC}(2015)^{10}$ \\
\hline Neurosyphilis & $\begin{array}{l}\text { - BPG } 2.4 \text { million units IM at } \\
\text { 1-week intervals for } 3 \text { weeks } \\
\text { (3 doses) } \\
\text { PP } 1.2 \text { million units IM, } 20 \\
\text { days } \\
\text { Alternative: } \\
\text { - } \quad \text { Doxycycline } 100 \mathrm{mg} \text { PO for } \\
30 \text { days or } \\
\text { Pregnant mother: } \\
\text { - } \quad \text { BPG } 2.4 \text { million IM units per } \\
851 \text { can for } 3 \text { weeks ( } 3 \text { doses, } \\
\text { maximum injection distance } \\
14 \text { days) } \\
\text { PP } 1.2 \text { million IM units once } \\
\text { a day for } 20 \text { days } \\
\text { Alternative: } \\
\text { Erythromycin } 4 \times 500 \text { mg PO } \\
\text { for } 30 \text { days }\end{array}$ & desensitization & $\begin{array}{l}\text { Penicillin G Crystal in } \\
\text { aqua, dose } 18-24 \text { million } \\
\text { units per day, IV dose 3-4 } \\
\text { million units every } 4 \\
\text { hours for 10-14 days } \\
\text { Alternative: } \\
\text { PP } 2.4 \text { million units IM } \\
\text { once a day plus } \\
\text { Probenecid } 4 \times 500 \mathrm{mg} \text { PO } \\
\text { for } 10-14 \text { days }\end{array}$ \\
\hline
\end{tabular}




\section{Management evaluation}

Treatment success was defined as a fourfold decrease in nontreponemal serological titers (or return to nonreactive results) after appropriate treatment, without signs or symptoms of persistent syphilis, and over a period of time according to the stage of syphilis infection and HIV status. fold is the 1:64 titer decreased to $1: 16$, or the $1: 16$ titer decreased to $1: 4.1,10$ Centers for Disease Control recommend evaluation of management at 6-month intervals until the titer decreases fourfold, unless primary or secondary syphilis patients with HIV infection are recommended for evaluation at $3,6,9,12$, and 24 months, and congenital syphilis is recommended for evaluation every 2 to 3 months .1 , ${ }^{10}$ Patients with latent syphilis fail treatment if there are clinical signs or symptoms of syphilis, a fourfold increase in serum nontreponemal test titer or no serological response (less than fourfold decrease in nontreponemal test titer) at 6,12 , and 24 months evaluation in 12-24 months after treatment with high initial titers $(>1: 32)$. The patient should be re-examined CSF, if the CSF examination reveals CNS involvement, re-treatment should be according to the management of neurosyphilis. ${ }^{20}$

Primary and secondary syphilis with proper management of about $15 \%$ to $20 \%$ serofast will persist and not achieve a fourfold decrease in titer. The CDC guidelines recommend an additional clinical examination and re-evaluation or examination of the CSF to rule out CNS infection. ${ }^{10}$ Patients with a CSF profile without CNS disease were re-treated with benzathine penicillin, 2.4 million units IM weekly for 3 weeks, although some were treated for neurosyphilis. Re-treatment of neurosyphilis was given if the CSF white blood cell count did not decrease 6 months after re-treatment or if the CSF-VDRL remained reactive after 2 years of treatment.20 Evaluation of the management of syphilis in patients with HIV and without HIV can be seen in table $8^{11}$

Table 8.Time to evaluate the management of syphilis in HIV patients and without HIV. ${ }^{11}$

\begin{tabular}{|c|c|c|c|}
\hline \multirow[t]{2}{*}{ Syphilis stage } & \multicolumn{2}{|c|}{ Syphilis titer re-evaluation time } & \multirow{2}{*}{$\begin{array}{l}\text { Initial } 4 \text { times titer } \\
\text { reduction time limit }\end{array}$} \\
\hline & $\mathrm{HIV}(+)$ & HIV(-) & \\
\hline $\begin{array}{l}\text { Primary and secondary } \\
\text { syphilis }\end{array}$ & $\begin{array}{l}3,6,9,12, \text { and } 24 \\
\text { months }\end{array}$ & 6 and 12 months & 6 to 12 months \\
\hline Early latent syphilis & $\begin{array}{l}6,12,18, \text { and } 24 \\
\text { months }\end{array}$ & 6,12 and 24 months & 12 to 24 months \\
\hline $\begin{array}{l}\text { Advanced latent syphilis } \\
\text { or unknown duration }\end{array}$ & $\begin{array}{l}6,12,18, \text { and } 24 \\
\text { months }\end{array}$ & 6,12 , and 24 months & 12 to 24 months \\
\hline Gummatous tertiary syphilis & $\begin{array}{l}6,12,18, \text { and } 24 \\
\text { months }\end{array}$ & 6,12 , and 24 months & 12 to 24 months \\
\hline $\begin{array}{l}\text { Cardiovascular } \\
\text { syphilis }\end{array}$ & $6,12,18$ and 24 months & 6,12 and 24 months & 12 to 24 months \\
\hline Neurosyphilis & $\begin{array}{l}3,6,9,12 \text { and } 24 \\
\text { months }\end{array}$ & $\begin{array}{l}6,12,18 \text { and } 24 \\
\text { months }\end{array}$ & 12 to 24 months \\
\hline
\end{tabular}

Evaluation of nontreponemal antibody serologic titers in congenital or pediatric syphilis should be performed during routine follow-up at 2, 4, 6, 12 and 15 months. Nontreponemal serological tests will become non-reactive within 6-12 months of adequate therapy. ${ }^{21}$ Treatment failure in congenital syphilis is characterized by a fixed or increasing nontreponemal titer at 6-12 months of age. Children with seropositive treponemal or non-treponemal titers at 18 months of age should be evaluated (eg, CSF examination) and reconsidered with parenteral penicillin for 10 days. 21,20

Prophylaxis or long-term maintenance management to prevent recurrence of syphilis in children with HIV infection does not exist. ${ }^{20} \mathrm{All}$ seroreactive infants (or infants of seroactive mothers at delivery) should undergo evaluation and serological tests (ie, nontreponemal testing) every 2-3 months until the test becomes nonreactive or the titer has decreased fourfold. Nontreponemal antibody titers should decrease by 3 months of age and should be nonreactive by 6 months of age in infants not infected or infected but well treated. Serological response after treatment may be slower in infants treated after the neonatal period. ${ }^{11,10,20}$

Treponemal testing in children is not used to evaluate response to treatment because results remain 
positive despite effective treatment. Treponemal antibodies from the mother can be found in infants up to 15 months of age. A reactive treponemal test after 18 months of age is diagnostic of congenital syphilis. A nonreactive nontreponemal test at 18 months of age does not require further evaluation or treatment, whereas if the nontreponemal test is reactive the infant should be reevaluated and treated for congenital syphilis. ${ }^{20}$ Failure to treat syphilis in children and adolescents is similar to that in adults i.e., there is no fourfold decrease in serum nontreponemal test titer for 6-12 months after therapy, a fourfold increase in serum nontreponemal test titer after initial reduction in treatment or clinical signs/symptoms of persistent disease or repeated. If the CSF examination does not confirm the diagnosis of neurosyphilis, the patient should be treated with benzathine penicillin G 2.4 million units IM at 1-week intervals for 3 weeks. ${ }^{10,20}$

In congenital syphilis with abnormal CSF, if Initial CSF examination shows pleocytosis, repeat lumbar puncture 6 months after therapy until the cell count is normal. ${ }^{21,20}$ Follow-up CSF examination can be used to evaluate changes in VDRL-CSF or CSF protein levels after therapy, but in HIV the parameter changes are slower than changes in CSF cell numbers. Neurosyphilis patients with HIV infection have longlasting CSF abnormalities and should be closely evaluated clinically. ${ }^{10,20}$

\section{Drug resistance}

The use of penicillin in the treatment of syphilis has not been reported to be resistant for more than 60 years. Syphilis patients with HIV only one patient reported failing penicillin therapy. Research with other alternative drugs is still limited with small samples, uncontrolled, and retrospective studies although there are studies of randomized trials. Erythromycin is not recommended because of drug resistance and tolerance, while doxycycline is a potential substitute for penicillin. 22

Doxycycline (100 mg orally twice daily for 14 days) is effective for the treatment of early syphilis with penicillin allergy. In a failure of treatment with doxycycline, syphilitic patients should be desensitized to penicillin and receive penicillin treatment. 4,11 Doxycycline response to the treatment of syphilis with HIV is $73-88 \%$, while in syphilis without HIV the average serological response is $83-100 \% .^{22}$

The use of ceftriaxone for the treatment of latent syphilis and neurologic failure has been reported in several cases. ${ }^{11}$ Ceftriaxone response to serological mean is 65-100\%. Response rates were lower in syphilis patients with HIV, especially patients with incomplete HIV suppression. Treatment failure was most commonly noted in patients with latent syphilis with HIV infection. ${ }^{22}$

The use of azithromycin ( $2 \mathrm{~g}$ orally in a single dose) in early syphilis has been reported to be resistant and treatment failure. Azithromycin should be used with caution and only used when treatment with penicillin or doxycycline is not possible.4,11 Azithromycin should not be used in patients with HIV.10 Azithromycinresistant strains are more common in the male population who have sex with men; azithromycinresistant syphilis during pregnancy increases the risk of congenital syphilis. ${ }^{11}$

\section{Treatment complications}

Complications of syphilis management can be in the form of a Jarisch-Herxheimer reaction and anaphylactic shock, therefore, after the injection of penicillin the patient was observed for 30 minutes. ${ }^{2}$ The Jarisch-Herxheimer reaction is a syndrome that occurs 12 hours after therapy, then resolves spontaneously within 24-36 hours. The Jarisch-Herxheimer reaction occurs in $1 / 3$ to $2 / 3$ of primary and secondary syphilis patients treated with penicillin. ${ }^{1}$ The JarischHerxheimer reaction is not a hypersensitivity reaction but rather the presence of cytokines triggered by dead lipoprotein T. pallidum, so penicillin therapy does not need to be discontinued.1,2,22

This reaction is thought to result from the release of lipoproteins, cytokines, and immune complexes from dead organisms.22 Clinical manifestations of fever, rash, malaise, headache, mucocutaneous lesions, lymphadenopathy tender to pressure, sore throat, malaise, and myalgia are seen in $10 \%$ to $35 \%$ of patients and are self-limiting. ${ }^{1}$ Treatment of syphilis in 
pregnant women can trigger the Jarisch-Herxheimer reaction. This reaction can trigger uterine contractions, premature birth, and impaired fetal heart rate, but the risk of a Jarisch-Herxheimer reaction is not a contraindication to the administration of penicillin in pregnant women. ${ }^{21}$ Acetaminophen or ibuprofen can be given to treat complaints. ${ }^{1,2}$

Penicillin allergic reactions may include urticaria, angioedema, or anaphylactic shock. Anaphylactic shock has symptoms of upper airway obstruction, bronchospasm, or hypotension. Treatment is epinephrine (adrenaline) 1:1000 IM, 0.5 mL followed by an IM/IV antihistamine (eg diphenhydramine $10 \mathrm{mg}$ ) and hydrocortisone IM/IV 100 mg.2,10Penicillin desensitization is an option in the following situations: (1) neurosyphilis in persons with a history of severe hypersensitivity reactions to penicillins; (2) tertiary syphilis in all penicillin-allergic patients; (3) all stages of syphilis in penicillin-allergic pregnant women; and (4) congenital syphilis in penicillin-allergic infants. 10,22

\section{Prevention}

Prevention of syphilis with HIV infection can be done by education, screening for syphilis and other sexually transmitted infections, as well as early detection of partners and therapy. Education in the form of not having sex before marriage, being faithful to a partner, using condoms, not consuming narcotics, psychotropic substances, and addictive substances (Drugs). ${ }^{2}$ The use of condoms and abstaining from risky sex is very important to prevent the transmission of syphilis and HIV.23,10 Screening for syphilis and other sexually transmitted infections is carried out in high-risk groups and pregnant women. ${ }^{2}$ Screening is also important in identifying asymptomatic patients. Sexually active MSM patients should be screened at least annually and every 3 to 6 months if at high risk (eg, the patient or sexual partner has multiple partners). ${ }^{1}$

Pregnant women are screened at the first prenatal visit, with re-examination early in the third trimester and at delivery if at high risk for syphilis. Screening of syphilis patients with sexually active HIV infection should be carried out at the first subsequent HIV evaluation at least annually, screening more frequently depending on individual risk behavior and local epidemiology. ${ }^{1,10}$ Early detection and therapy of sexual partners with syphilis is carried out if sexual intercourse occurs within 3 months after the onset of primary syphilis symptoms, 6 months after the onset of secondary syphilis symptoms, 12 months in patients with early latent syphilis and 24 months in patients with latent syphilis. Examination and laboratory results suggest syphilis in sexual partners can be given therapy. ${ }^{2}$

In communities and populations at high risk of congenital syphilis, serologic tests and sexual history should be checked at 28 weeks gestation and delivery. This examination as part of the management of pregnant women with syphilis, information about the treatment of sexual partners should be known to assess the risk of reinfection. ${ }^{21,20}$ Routine screening of serum from newborns or cord blood is not recommended. Maternal serum serologic tests are preferred over infant serum tests because serologic tests of infant serum may become nonreactive if the mother's serologic test results are low or the mother is infected with syphilis in late pregnancy. Infants with HIV infection in a population at high risk for congenital syphilis should not leave the hospital unless the mother's serologic status is at least once during pregnancy and at delivery. 20

\section{Prognosis}

The prognosis for syphilis in HIV is worse than for syphilis without HIV. Neurosyphilis is more common in syphilis patients with HIV infection, clinical manifestations such as uveitis or meningitis are more common. 4 Treponema pallidum remains sensitive to penicillin despite its use for decades. Treatment failure can occur and more often in syphilis patients with HIV infection, penicillin treatment is very effective for treating the infection at all stages of syphilis. Primary and secondary syphilis mostly have a resolution of symptoms, without sequelae even without treatment. In tertiary syphilis, there can be permanent damage to vital organs such as gumma, cardiovascular or CNS involvement. ${ }^{1}$ In a 2016 study by Sophie et al., two patients from 12 cases of ocular syphilis experienced 
sequelae of permanent blindness despite treatment. 24 The prognosis of the fetus depends on the diagnosis of syphilis in the pregnant woman at the time of presentation for antenatal care. Congenital syphilis is a disease that can be prevented through antenatal services to reach pregnant women with syphilis. ${ }^{21}$

\section{Conclusion}

Syphilis and HIV have a reciprocal relationship, HIV infection causes a decrease in the body's immunity so it is very easy to be infected with various other diseases such as syphilis, while syphilis also increases the risk of HIV transmission. The prevalence of syphilis in HIV was greater than that of syphilis without HIV and was more common in the MSM group. Patients with syphilis should be tested for HIV infection and HIV patients should be tested for syphilis infection. The diagnosis of syphilis is based on a complete history including sexual history, clinical manifestations, and examination. Serological examination is a tool for the diagnosis of syphilis in syphilis patients with HIV infection and without HIV infection. Penicillin is still the gold standard for the management of syphilis with or without HIV infection, there is no difference in therapy between syphilis patients with HIV infection and without HIV infection. Prevention of syphilis in HIV can be done by education, screening for syphilis and other STIs, as well as early detection and therapy in partners. Syphilis patients with HIV infection are more at risk of developing neurosyphilis.

\section{References}

1. Tuddenham SA, Zenilman JM. Syphilis. In: Kang S, Amagai M, Bruckner AL, Enk AH, Margolis DJ, McMichael AJ, et al., editors. Fitzpatrick's Dermatology In General Medicine. 9th ed. New York: McGraw-Hill Medical; 2019; 3145-72.

2. Rowawi R, Djayakusumah TS, Achdiat pati A. Syphilis in HIV/AIDS Patients. In: Hidayati AN, Daili $S$ fahmi, Niode nurdjannah jane, Indriatmi W, Budiono santoso edy, Barakbah $\mathrm{J}$, editors. Manifestations and Management of Skin and Sexual Disorders in HIV/AIDS Patients. Indonesia: FKUI Publishing Agency; 2018; 19-50.

3. Ministry of Health of the Republic of Indonesia.
Indonesia Health Profile 2019. Hardhana B, Sibuea F, Widiantini W, editors. Ministry of Health of the Republic of Indonesia. Jakarta; 2020; 157-160

4. US Department of Health and Human Services. Syphilis. In: Guidelines for the Prevention and Treatment of Opportunistic Infections in Adults and Adolescents with HIV: Recommendations from the Centers for Disease Control and Prevention, the National Institutes of Health, and the HIV Medicine Association of the Inf. [Internet]. USA: MMWR Recommendations and Reports; 2020; 1-15. Available from: http://aidsinfo.nih.gov/contentfiles/lvguideli nes/adult_oi.pdf.Accessed

5. Directorate General of Disease Control and Environmental Health, Ministry of Health of the Republic of Indonesia. Syphilis Management Guidelines for Syphilis Control in Primary Health Care. Dai SF, Indriatmi W, Wiweko SN, Dewi H, Tanudjaya F, Wignall S, et al., editors. Jakarta: Ministry of Health of the Republic of Indonesia; 2013; 1-24.

6. Centers for Disease Control and Prevention. Sexually Transmitted Disease Surveillance 2016. Atlanta: US Department of Health and Human Services; 2017; 21-28.

7. Centers for Disease Control and Prevention. Sexually Transmitted Disease Surveillance 2017 [Internet]. Atlanta: US Department of Health and Human Services; 2018; 2: 26. Available from: https: / / www.cdc.gov/std/stats 17/2017-STDSurveillance-Report_CDC-clearance-

9.10.18.pdf\%OAhttp://www.cdc.gov/std/stats $12 /$

8. Indriatmi W. Syphilis. In: Daili SF, Nilasari H, Makes WIB, Zubiar F, Roman R, Pudjiati SR, editors. Sexually Transmitted Infections. 5th ed. Jakarta: Faculty of Medicine, University of Indonesia; 2017; 103-29.

9. Seña AC, Zhang XH, Li T, Zheng HP, Yang B, Yang LG, et al. A Systematic Review of Syphilis Serological Treatment Outcomes in HIVInfected and HIV-Uninfected Persons: Rethinking the Significance of Serological NonResponsiveness and The Serofast State After Therapy. BMC Infect Dis [Internet]. 2015; 15(1): 1-15. Available from: http:/ / dx.doi.org/10.1186/s 12879-0151209-0

10. Workowski KA, Bolan GA. Syphilis. In: Moolenaar RL, Casey CG, Rutledge TF, Johnson DC, Boyd MF, LaPete MA, et al., editors. Sexually Transmitted Diseases Treatment Guidelines, 2015. Atlanta: MMWR Recommendations and Reports; 2015; 35-51. 
11. Department of Health AIDS Institute. Clinical Guidelines Program: Management of Syphilis in Patients with HIV. New York: Department of Health AIDS Institute; 2018; 1-30 p.m.

12. Rahadiyanti DD, Damayanti. Secondary Syphilis in HIV Patients: A Case Report (Secondary Syphilis and Human immunodeficiency virus (HIV) Coinfection: A Case Report. Dermatology and Venereology Berk- Period Dermatology Venereol.2018; 30(2): 178-84.

13. Sparling PF, Swartz MN, Musher DM, Healy BP. Clinical Manifestations of Syphilis. In: Holmes KK, Sparling PF, Stamm WE, Piot P, Wasserheit JN, Corey L, et al., editors. Sexually Transmitted Diseases. 4th ed. New York: McGraw-Hill Medical; 2008; 661-84.

14. Crowson N, Margo C, Mihm M. Treponemal Disease. In: Elder DE, Elenitsas R, Rosenbach M, Murphy G, I RA, Xu x, editors. Lever's Histopathology of the Skin. 11th ed. Philadelphia: Wolter Kluwer; 2015; 1418-45.

15. World Health Organization. WHO Guidelines for The Treatment of Treponema Pallidum (Syphilis). Switzerland: World Health Organization; 2016; 1-48

16. Ministry of Health of the Republic of Indonesia. National Guidelines for Handling Sexually Transmitted Infections 2016. Jakarta; 2016; 1166

17. Tuddenham S, Ghanem KG. Emerging Trends and Persistent Challenges in the Management of Adult Syphilis. BMC Infect Dis [Internet]. 2015; 15(1): 1-8. Available from: http: / /dx.doi.org/10.1186/s12879-0151028-3
18. Clement ME, Okeke NL, Hicks CB. Treatment of syphilis: A systematic review. JAMA - J Am Med Assoc. 2014; 312(18): 1905-17.

19. Widaty S, Soebono H, Nilasari H, Listiawan MY, Siswati AS, Triwahyudi D, et al. syphilis. In: Widaty S, Soebono H, Nilasari H, Listiawan MY, Siswati AS, Triwahyudi D, et al., editors. Clinical practice guide for dermatologists and gynecologists in Indonesia. Jakarta; 2017; 372-372.

20. US Department of Health and Human Services. Syphilis. In: Morbidity and Mortality Weekly Report Guidelines for the Prevention and Treatment of Opportunistic Infections Among HIV-Exposed and HIV-Infected Children: Recommendations from $\mathrm{CDC}$, the National Institutes of Health, the HIV Medicine Association of the I. USA: MMWR Recommendations and Report; 2020; 6-9.

21. Shafii T, Radolf JD, Sanchez PJ, Schulz KF, Murphy FK. Congenital Syphilis. In: Holmes KK, Sparling PF, Stamm WE, Piot P, Wasserheit JN, Corey L, et al., editors. Sexually Transmitted Diseases. 4th ed. New York; 2008; 1577-607.

22. Clement ME, Okeke NL, Hicks CB. Review: Treatment of Syphilis A Systematic Review. JAMA J. 2014; 312(18): 1905-17.

23. Stoltey JE, Cohen SE. Syphilis Transmission: A Review of The Current Evidence. Sex Heal J. 2015; 12(2): 103-9.

24. Woolston S, Cohen SE, Fanfair RN, Lewis SC, Marra CM, Golden MR. A Cluster of Ocular Syphilis Cases-Seattle, Washington, and San Francisco, California, 2014-2015. MMWR Morb Mortal Wkly Rep. 2016; 64(40): 1150-1. 